\title{
Insecticide resistance in malaria-transmitting mosquitoes in Zimbabwe: a review
}

White Soko ${ }^{1,4^{*}}$, Moses J. Chimbari ${ }^{1,2}$ and Samson Mukaratirwa ${ }^{3}$

\begin{abstract}
Malaria is a global public health problem, with about 3.2 billion people at risk of infection. The populations at risk mainly reside in Africa, Asia and America, with African populations accounting for the largest burden of the disease. In 2013, close to 198 million malaria cases were reported, leading to 584,000 deaths. Much (90\%) of the mortality rates were recorded from the World Health Organization (WHO) database in the African region and $78 \%$ of these occurred in children under the age of five. In Zimbabwe, approximately half of the population is at risk of infection with malaria.

Insecticide residual spraying (IRS) has been documented as an effective way to control malaria and has been adopted globally by the WHO and national governments. However, both insecticide resistance and climate change threaten to reverse the progress made by IRS in malaria control. Resistance has been reported in all four classes of insecticides approved by the WHO for vector control intervention. Variability of environmental temperature is suspected to complicate the situation through alteration in the genetic structure, and enzyme and protein profiles of mosquitoes. In Zimbabwe, little research has been done on the interaction between climate change, temperature variability and insecticide resistance in malarial mosquitoes over time. Such information is important for informing policies on insecticide selection for IRS.

We reviewed literature on insecticide sensitivity among malarial mosquitoes in Zimbabwe from 1972 to 2014. International peer-reviewed articles on insecticide sensitivity in Zimbabwe, published in English in this time period, were searched using MEDLINE ${ }^{\circledR}$ (PubMed), Google Scholar, Google and grey literature. Eight publications were eligible for the present study, with one of the articles being a review paper. Six articles covered insecticide resistance, while the other two articles, published in 2000, were about the absence of resistance. Contradicting resistance results were reported in 2014.

The insecticide sensitivity status and distribution of insecticide resistance in mosquitoes are still under debate in Zimbabwe, as studies report differing results. The resistance trend in Zimbabwe is characterised by fluctuations in the status of the sensitivity of existing insecticides. Inconsistencies in data collection methods may be responsible for the inconsistencies in the results. None of the studies have determined a link between climate/temperature variability and insecticide resistance as yet. The current insecticide sensitivity status of mosquitoes still needs to be verified.
\end{abstract}

Keywords: Malaria, Mosquitoes, Vector control, Insecticide resistance, Insecticide sensitivity, Zimbabwe

\footnotetext{
* Correspondence: 213573997@stu.ukzn.ca.za

${ }^{1}$ School of Nursing and Public Health, University of KwaZulu-Natal, Howard

Campus, Durban 4001, South Africa

${ }^{4}$ Ministry of Health and Child Care, National Institute of Health Research, P.O.

Box CY 573, Causeway, Zimbabwe

Full list of author information is available at the end of the article
}

\section{Biomed Central}

(c) 2015 Soko et al. Open Access This article is distributed under the terms of the Creative Commons Attribution 4.0 International License (http://creativecommons.org/licenses/by/4.0/), which permits unrestricted use, distribution, and reproduction in any medium, provided you give appropriate credit to the original author(s) and the source, provide a link to the Creative Commons license, and indicate if changes were made. The Creative Commons Public Domain Dedication waiver (http://creativecommons.org/publicdomain/zero/1.0/) applies to the data made available in this article, unless otherwise stated. 


\section{Introduction}

Malaria is a vector-borne disease endemic in tropical and subtropical areas [1]. Close to 3.2 billion people are at risk of infection [2]. In 2013, an estimated 584,000 deaths from malaria were reported worldwide, with most (90\%) of the deaths occurring in the African region (as recorded in the World Health Organization [WHO] database). Seventy-eight per cent (78\%) of these deaths occurred in children under five years of age [2].

Zimbabwe has a population of about 13 million [3], with half of that population living in malaria-endemic areas [4, 5]. Anopheles gambiae complex, Anopheles arabiensis Patton and Anopheles gambiae sensu stricto Giles mosquitoes are responsible for the transmission of malaria in the country [6,7], with An. arabiensis mosquitoes responsible for the majority of the transmission $[7,8]$. The advent of climate change, especially increases in temperature, threatens to complicate the situation by extending the geographical distribution of malaria globally [9], in parts of Europe [10], Asia [11] and Africa [12-14].

Insecticide residual spraying (IRS) and long-lasting insecticide treated nets (LLINs) are the major intervention strategies aimed at interrupting malaria transmission [15]. In Zimbabwe, malaria case management, vector control using IRS and LLINs, and health education form the vanguard of the malaria control programme [4]. However, the WHO [16] has noted that insecticide resistance could derail disease control, with Krostad [17] expressing the same sentiment, saying that insecticide resistance was threatening to reverse the progress made by IRS in malaria control thus far.

Insecticide resistance involves changes in one or more genes, leading to the reduction in insecticide sensitivity of an insect population. This is manifested in an insecticide's repeated failure to achieve the projected level of control when used following the recommendations for that species [18]. The changes leading to resistance may not only be genetic, but also enzymatic; at times genetically related and at times not [19-21]. Wood et al. [22] indicated that insecticide resistance could happen due to selection pressure and increasing mutation rates.

Insect resistance to dichlorodiphenyltrichloroethane (DDT) emerged in the 1940s, with the first conclusive study being conducted on the Culex molestus mosquitoes in 1947 in Italy. Insecticide resistance was also reported among Anopheles sacharovi mosquitoes in Greece in 1951 [23]. In 1955, it was reported in the $A n$. gambiae species in Nigeria [24]. Thereafter, resistance has been reported in more than 500 insects, 50 of which transmit malaria parasites in humans [21, 25].

Insecticide resistance in malaria vector populations is widespread and covers all classes of insecticides recommended for public health use [26-30]. Pyrethroid resistance was first reported in Ivory Coast in 1993 [31]. Knockdown resistance $(\mathrm{kdr})$ is currently the most common form of insecticide resistance. Outside Africa, $k d r$ has been found in several malarial mosquito species, including Anopheles stephensi and Anopheles culicifacies [32, 33]. In Africa, kdr has been reported in a number of countries: in West Africa (Ivory Coast, Burkina Faso, Benin) [31, 34], Central Africa (Cameroon) [28], East Africa (Kenya) [35] and Southern Africa (South Africa and Zimbabwe) [36, 37].

Although insecticides have played a pivotal role in both agricultural and public health sectors, their widespread use has been linked to the development of insecticide resistance $[38,39]$. The high frequency of $k d r$ mutations in malaria vectors has been attributed to an extensive use of DDT to control agricultural pests in Africa [38] and Central America [40, 41]. Use of insecticides in IRS, and on bed nets and curtains has been associated with insecticide resistance in East Africa [35], Malaysia [42] and Sri Lanka [40].

Currently, there is insufficient information on the status of insecticide resistance in Zimbabwe. The available information may be underestimating the situation; the level of insecticide resistance may have in fact increased. Furthermore climate change, particularly the effects of temperature, may have influenced resistance [43, 44], but there is no concrete evidence of this as yet. We reviewed insecticide resistance data collected in the past 42 years in Zimbabwe and assessed the changes that have taken place. We then made recommendations for sustaining the progress made in malaria control through the use of insecticides.

\section{Review}

\section{Materials and methods}

We reviewed international peer-reviewed articles, published in English between 1972 and 2014, which assess the insecticide sensitivity status of mosquitoes in Zimbabwe. Selection for eligible studies was done through a literature search on MEDLINE ${ }^{\bullet}$ (PubMed), Google Scholar, Google and grey literature. The search terms were 'insecticide resistance', 'sensitivity', 'temperature', 'vector mosquitoes' and 'Zimbabwe'. More literature was found using snowball sampling: that is identifying other papers listed from reference lists of initially identified articles. The abstracts of articles were read first, with the full articles read only if applicable. Papers were deemed eligible if they were about the insecticide sensitivity status of An. gambiae s.l. complex and Anopheles funestus mosquitoes in Zimbabwe.

\section{Results}

History of insecticide use in malaria control in Zimbabwe Although DDT was the first insecticide to be used in IRS in Greece in 1947, by 1951 the insecticide had been 
effectively used in 22 countries [45]. In Zimbabwe, IRS began in 1949, using benzene hexachloride (BHC) [46]. However, some studies suggest that IRS was actually introduced in 1945, but launched in 1949 [47] (see Table 1). Published and grey sources state that between 1945 and 2003, BHC, DDT and pyrethroids were all used in IRS [48, 49; unpublished sources]. Following the discovery of $\mathrm{BHC}$ resistance in $\mathrm{An}$. arabiensis mosquitoes in the Chiredzi district, BHC was replaced with DDT [48]. It should also be noted that although DDT was introduced in Zimbabwe in 1960, it was not extensively used until 1974, when resistance to BHC was reported [49]. Between 1976 and 1980, the control programme was disturbed by political unrest but soon after independence in 1980, IRS was resumed, using DDT.

From 1987 to 1991, DDT and deltamethrin were used alternately on malarial mosquitoes and tsetse flies. Other

Table 1 Summary of malaria control programmes using IRS in Zimbabwe between 1945 and 2004

\begin{tabular}{|c|c|c|}
\hline Author & Year & $\begin{array}{l}\text { Milestones in insecticide } \\
\text { use in Zimbabwe }\end{array}$ \\
\hline \multirow[t]{6}{*}{ Mabaso et al., [47] } & 1945 & IRS introduced \\
\hline & 1949 & Programme launched \\
\hline & $1957-62$ & DDT and BHC used \\
\hline & 1972-73 & $\begin{array}{l}\text { BHC (equally effective as } \\
\text { DDT but cheaper) }\end{array}$ \\
\hline & $1974-87$ & $\begin{array}{l}\mathrm{DDT} \text { (due to resistance } \\
\text { to } \mathrm{BHC} \text { ) }\end{array}$ \\
\hline & 1988-2000 & $\begin{array}{l}\text { Deltamethrin and lambda- } \\
\text { cyhalothrin (policy change) }\end{array}$ \\
\hline UNEP, [50] & 2004 & $\begin{array}{l}\text { DDT was reintroduced to } \\
\text { complement pyrethroids }\end{array}$ \\
\hline \multirow[t]{8}{*}{$\begin{array}{l}\text { Unpublished } \\
\text { sources/reports }\end{array}$} & 1949-1960 & $\begin{array}{l}\text { BHC used for the countrywide } \\
\text { malaria control programme, } \\
\text { while dieldrin was used in } \\
\text { sugar estates }\end{array}$ \\
\hline & 1960 & $\begin{array}{l}\text { DDT was used to complement } \\
\text { BHC on a small scale }\end{array}$ \\
\hline & 1974-1976 & $\begin{array}{l}\text { DDT became a principal } \\
\text { insecticide for malaria control }\end{array}$ \\
\hline & 1976-80 & $\begin{array}{l}\text { No insecticide used as spraying } \\
\text { activities were disrupted by } \\
\text { war of liberation }\end{array}$ \\
\hline & 1980-1987 & Extensive use of DDT resumed \\
\hline & 1987-1991 & $\begin{array}{l}\text { DDT used, interchangeable } \\
\text { with deltamethrin }\end{array}$ \\
\hline & 1991 & $\begin{array}{l}\text { DDT abandoned (decision to } \\
\text { abandon was motivated by } \\
\text { need to protect tobacco export }\end{array}$ \\
\hline & $1991-2003$ & $\begin{array}{l}\text { Only pyrethroids (deltamethrin, } \\
\text { lambda-cyhalothrin and alpha- } \\
\text { cypermethrin) were used }\end{array}$ \\
\hline UNEP, [50] & 2004 & $\begin{array}{l}\text { DDT was reintroduced to } \\
\text { complement pyrethroids }\end{array}$ \\
\hline
\end{tabular}

sources indicate that DDT was used between 1988 and 2000 [47]. However, DDT use was short-lived as environmentalists successfully lobbied for its ban in order to manage bed bug resistance. The insecticide's lipophilic nature, which resulted in its accumulation in human adipose tissue, meat-eating birds and the environment at large, was another reason for its ban [51]. However, DDT was readopted in 2004 [50] to complement pyrethroids [37].

\section{Geographical distribution, causes and mechanisms of insecticide-resistant distribution over time}

An online literature search to review the resistance status of mosquitoes in the Afrotropical region, focusing on the period from 2001 to 2012, reaffirmed that malaria vectors were resistant to all insecticides recommended by the WHO for vector control in Africa. The same study reports resistance of An. gambiae s.l and $A n$. funestus mosquitoes to organochlorines, carbamates and pyrethroids in Zimbabwe (see Fig. 1) [52].

\section{Case studies on insecticide resistance in Zimbabwe}

In Zimbabwe, eight papers investigating insecticide resistance (1972-2014) have been published (see Table 2). These papers indicate that insecticide resistance levels have been changing over time. The first case of insecticide resistance (to $\mathrm{BHC}$ ) was reported in Chiredzi in the early 1970s [48]. However, because Green's original text (1972), which described this, could not be accessed, successive articles citing Green's work, such as ones by Masendu et al. [54] and Munhenga et al. [37], were extrapolated on. In 1980, Crees reported on the susceptibility of mosquitoes in the areas of Chiredzi, Mtoko and Manjolo (unpublished data and not shown on Table 1). A study by Manokore et al. [49] documented that in the Gokwe region of Zimbabwe, there is an absence of insecticide resistance in mosquitoes to deltamethrin, alpha-cypermethrin, lambda-cyhalothrin and DDT. But after this study was conducted, insecticide resistance in An. arabiensis mosquitoes has been slowly spreading and increasing in intensity [54]. Munhenga et al. [37] further confirmed the presence of insecticide resistance to permethrin and DDT in An. arabiensis mosquitoes in Gokwe. Three papers reported insecticide resistance in An. funestus mosquitoes against organophosphates, pyrethroids and carbamates $[5,52,55]$. The two recent nationwide surveys contradict each other: The one conducted by the President's Malaria Initiative (PMI) [5] reports insecticide resistance in An. funestus mosquitoes, while the other one by Lukwa et al. [56] disputes this as well as previous findings.

The focus of research on insecticide sensitivity of mosquitoes has been Gokwe, where four studies have been conducted [37, 49, 54,56]. This study site was chosen 

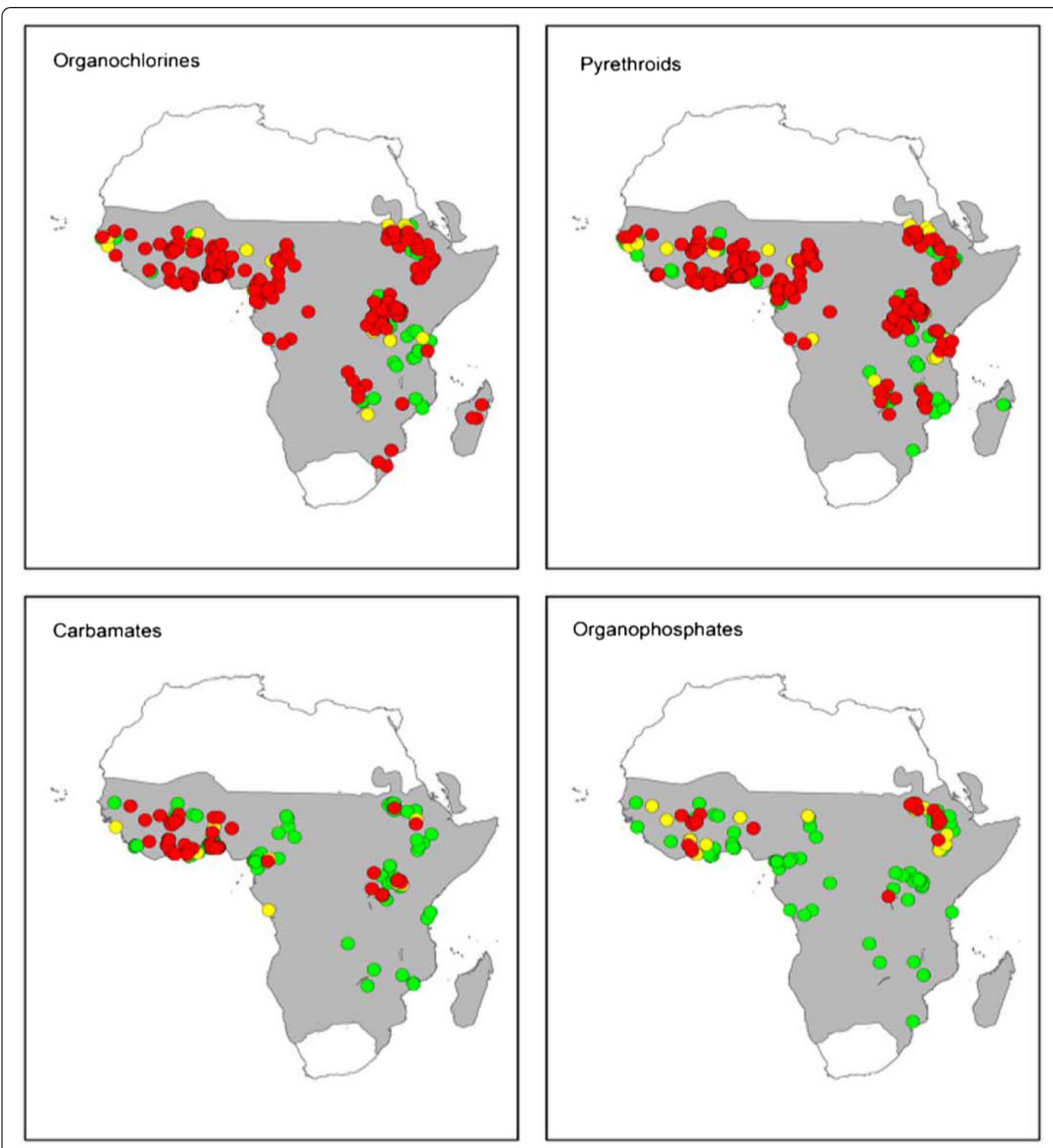

- Confirmed resistance ( $<90 \%$ mortality)

- Possible resistance $(90-97 \%$ mortality)

- Susceptibility (98-100\% mortality)

Predicted vector distribution

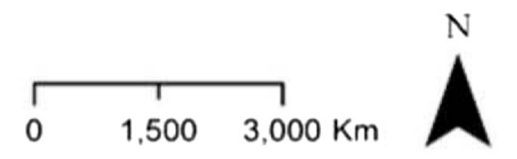

Fig. 1 Distribution of insecticide resistance in An. gambiae s.l. mosquitoes between 2001 and 2012 [53] 
Table 2 Summary of studies that assessed insecticide resistance in malarial mosquitoes between 1972 and 2014 in Zimbabwe

\begin{tabular}{|c|c|c|c|c|c|}
\hline Author [reference] & Objectives & $\begin{array}{l}\text { Mosquito species } \\
\text { studied }\end{array}$ & Study area & Method & Outcome \\
\hline \multirow[t]{2}{*}{ Knox et al. [52] } & \multirow{2}{*}{$\begin{array}{l}\text { To introduce and demonstrate the } \\
\text { usefulness of the online mapping } \\
\text { tool IR Mapper }\end{array}$} & An. gambiae & \multirow{2}{*}{$\begin{array}{l}\text { African region (results presented } \\
\text { are for Zimbabwe) }\end{array}$} & \multirow{2}{*}{$\begin{array}{l}\text { Systematic search of published } \\
\text { peer-reviewed literature }\end{array}$} & \multirow{2}{*}{$\begin{array}{l}\text { An. gambiae and An. funestus were } \\
\text { resistant to organophosphates and } \\
\text { pyrethroids. }\end{array}$} \\
\hline & & An. funestus & & & \\
\hline Lukwa et al. [56] & $\begin{array}{l}\text { To conduct a nation-wide assessment } \\
\text { of insecticide susceptibility in wild } \\
\text { populations of An. gambiae s.l. }\end{array}$ & An. gambiae s.l & $\begin{array}{l}\text { Thirteen (13) sentinel sites covering } \\
\text { all malaria-endemic regions in } \\
\text { Zimbabwe }\end{array}$ & $\begin{array}{l}\text { All sites were sampled for } \\
\text { resistance in malarial } \\
\text { mosquitoes between } 2011 \text { and } \\
2012 \text {. }\end{array}$ & $\begin{array}{l}\text { No evidence of phenotypic resistance } \\
\text { to any of the four insecticide classes } \\
\text { in An. gambiae s.l. collected across } \\
\text { different eco-epidemiology areas in } \\
\text { Zimbabwe. }\end{array}$ \\
\hline \multirow[t]{2}{*}{ PMI Africa IRS. [5] } & \multirow{2}{*}{$\begin{array}{l}\text { To determine insecticide susceptibility } \\
\text { for malarial mosquito species from } \\
\text { sentinel sites throughout Zimbabwe }\end{array}$} & An. gambiae s.l & \multirow{2}{*}{$\begin{array}{l}\text { Nine (9) sentinel sites in various } \\
\text { provinces in Zimbabwe }\end{array}$} & \multirow{2}{*}{$\begin{array}{l}\text { WHO susceptibility tests were } \\
\text { done using impregnated } \\
\text { papers and test kits on wild } \\
\text { caught An. gambiae s.l. and An. } \\
\text { funestus mosquitoes. }\end{array}$} & \multirow{2}{*}{$\begin{array}{l}\text { An. funestus mosquitoes were } \\
\text { resistant to pyrethroids (lambda- } \\
\text { cyhalothrin and etofenprox). }\end{array}$} \\
\hline & & An. funestus & & & \\
\hline Choi et al. [55] & $\begin{array}{l}\text { To investigate the biological attributes } \\
\text { of insecticide resistance and parasite } \\
\text { infection rates that both impact on } \\
\text { malaria vector control activities }\end{array}$ & An. funestus & Honde Valley & $\begin{array}{l}\text { WHO susceptibility tests were } \\
\text { done using impregnated } \\
\text { papers and test kits on } \\
\text { mosquitoes were collected } \\
\text { between February and March } \\
2014 \text {. }\end{array}$ & $\begin{array}{l}\text { An. funestus populations were } \\
\text { resistant to pyrethroids and } \\
\text { carbamates. }\end{array}$ \\
\hline Munhenga et al. [37] & $\begin{array}{l}\text { To determine insecticide susceptibility } \\
\text { of An. arabiensis using the WHO } \\
\text { insecticide susceptibility method. }\end{array}$ & An. arabiensis & Gokwe & $\begin{array}{l}\text { WHO susceptibility tests were } \\
\text { done using impregnated } \\
\text { papers and test kits on wild } \\
\text { caught An. arabiensis and F1 } \\
\text { progeny of the same } \\
\text { mosquitoes. }\end{array}$ & $\begin{array}{l}\text { Study confirmed the presence of } \\
\text { permethrin and DDT resistance in An. } \\
\text { gambiae mosquitoes in the Gwave } \\
\text { area of Gokwe. }\end{array}$ \\
\hline Masendu et al. [54] & $\begin{array}{l}\text { To determine the distribution of malaria } \\
\text { vectors in Zimbabwe together with the } \\
\text { extent of insecticide resistance in } \\
\text { different assemblages }\end{array}$ & $\begin{array}{l}\text { An. gambiae Giles s.s, } \\
\text { An. arabiensis Patton, } \\
\text { An. merus Dönitz and } \\
\text { An. quadrinnulatus } \\
\text { Theobald (species A). }\end{array}$ & Zimbabwe & $\begin{array}{l}\text { National anopheline mosquito } \\
\text { survey conducted between } \\
1992 \text { and } 2002 \text { at sites broadly } \\
\text { categorised based on land use, } \\
\text { patterns and location. }\end{array}$ & $\begin{array}{l}\text { DDT resistance was detected in An. } \\
\text { arabiensis collected from market } \\
\text { gardens in Gokwe. }\end{array}$ \\
\hline Manokore et al. [49] & $\begin{array}{l}\text { To determine insecticide susceptibility } \\
\text { of field caught } A n \text {. arabiensis and F1 } \\
\text { progeny reared from these field-caught } \\
\text { females An. arabiensis Patton mosquitoes } \\
\text { to WHO recommended insecticides }\end{array}$ & An. arabiensis Patton & $\begin{array}{l}\text { Gokwe district in the Midlands } \\
\text { province }\end{array}$ & $\begin{array}{l}\text { Wild caught An. arabiensis } \\
\text { mosquitoes were tested for } \\
\text { insecticide sensitivity using the } \\
\text { WHO susceptibility test method. }\end{array}$ & $\begin{array}{l}\text { F1 progeny of field-caught females } \\
\text { that were identified as An. arabiensis } \\
\text { Patton were completely susceptible } \\
\text { to deltamethrin, alpha-cypermethrin, } \\
\text { lambda-cyhalothrin and DDT. }\end{array}$ \\
\hline Green, [48] & Unknown & Unknown & Chiredzi district & $\begin{array}{l}\text { Unknown mosquitoes were } \\
\text { tested against BHC }\end{array}$ & $\begin{array}{l}\text { Insecticide resistance to } \mathrm{BHC} \text { reported } \\
\text { in Chiredzi }\end{array}$ \\
\hline
\end{tabular}


because of the presence of a National Institute of Health Research satellite station established to monitor malaria entomology in the area. Coetzee et al. [57] reiterated that early insecticide resistance distribution maps were limited, as they tended to reflect the distribution of entomologists rather than mosquito species. Perhaps this explains why this area has been so over researched.

Some of the sites that have been sampled by Masendu et al. [54] and Lukwa et al. [56] are shown in Figs. 2 and 3 . Contrary to the two recent studies $[5,56]$, previous studies observed insecticide resistance in mosquitoes in the Gwave area of Gokwe in 2008, and the first case of resistance in Hippo Valley in 1972 [37, 48, 54].

\section{Causes of insecticide resistance}

\section{Agricultural and public health practices}

In Zimbabwe, agricultural practices have influenced the occurrence of resistance in malarial mosquitoes. Zimbabwe started using DDT as a pesticide in the agro-industry and for vector control programmes in 1969 [58]. The use of this pesticide resulted in a remarkable increase in agricultural production and improvements in human health as a result of controlling agricultural pests and arthropods that transmit animal and human diseases. However in 1972, DDT use was banned in the agro-industry because of public health concerns. Its use was eventually restricted to vector control programmes only [51]. A number of studies carried out after DDT was banned in Zimbabwe showed that the areas where DDT had been used (Esigodini, Nyanga, Kwekwe, Kadoma, Bulawayo, Harare and Kariba) were indeed polluted with organochlorine compounds $[59,60]$. These insecticide pollutants might have exposed mosquitos to high or sublethal doses of the insecticides, which could have led to the development of insecticide resistance strains in malarial mosquitoes in some parts of the country.

\section{Climate change}

As early as in the 1930s, Leeson [61] observed that mosquitoes were migrating from low to high altitude areas along river valleys in Zimbabwe. Ebi et al. [62] predicted that Zimbabwean highlands will be climatologically habitable to malarial mosquitoes by 2015 [13]. Similarly, Komen et al. [63] asserted that temperature was a critical factor in the transmission of malaria in the Limpopo province of South Africa [63], which shares a border

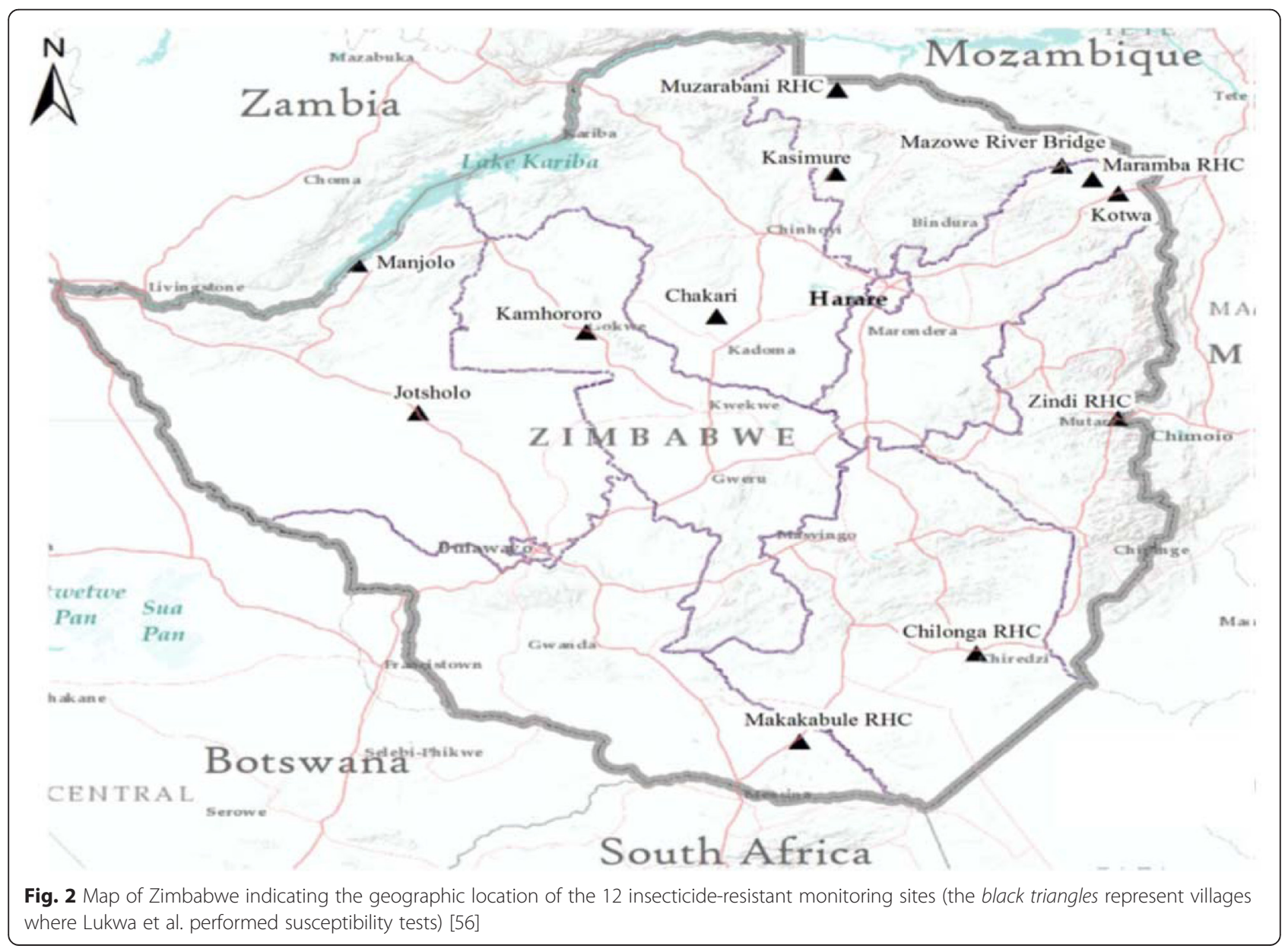




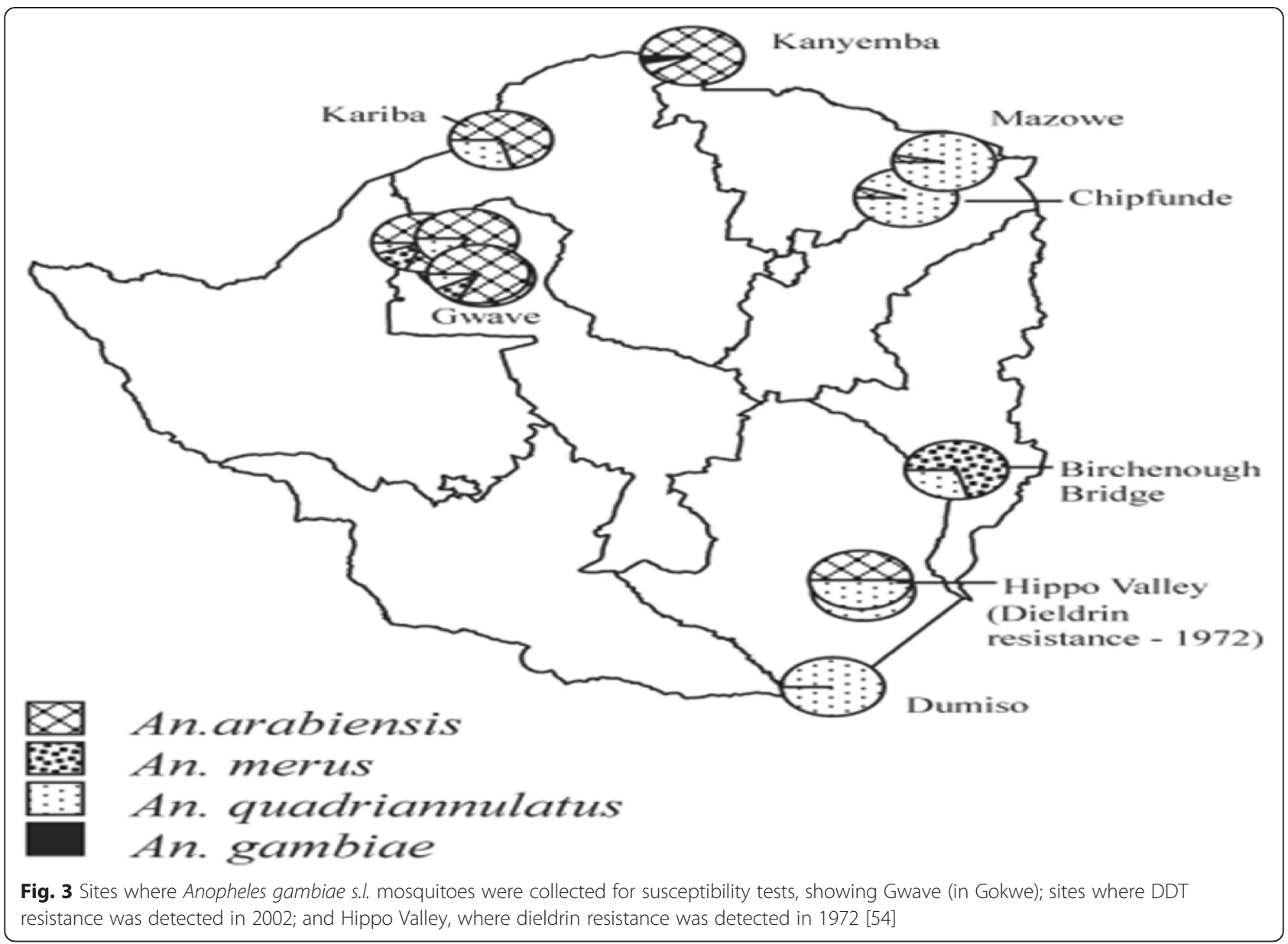

with Zimbabwe. Mabaso et al. [64] also acknowledged that year-to-year variations in malaria incidences were mainly driven by climatic covariate, although this was not the only factor. In this context, it is imperative that we acquire more knowledge on mosquitoes' responses and behaviours in the anticipated warmer climatic conditions.

\section{Main mechanism of resistance}

Of the six studies that reported resistance [5, 37, 48, 52, $54,55]$, only two determined the mechanism of resistance. Monooxygenase was responsible for resistance in An. funestus mosquitoes in Honde Valley [55]. Both East and West African kdr were identified as being responsible for resistance in An. arabiensis mosquitoes in Gokwe [37].

\section{Implications of malaria control}

In Zimbabwe, the effect of resistance on vector control remains unknown. Although there is no scientific evidence to support the link, the Gokwe region, where resistance was reported on two occasions, has become one of the hubs of malaria transmission. There have also been sporadic outbreaks of malaria infection in the Honde Valley and Burma Valley. There have been no studies in Zimbabwe investigating the effect of resistance on malaria control, however, Corbel and N'Guessan [21] and Ranson et al. [19] have indicated that insecticide resistance is disruptive to malaria control programmes. The brief studies done in South Africa [36], Malawi [65], Burundi [66] and on the coast of Bioko Island, West Africa [67], all support the hypothesis that resistance is able to disrupt malaria control programmes. On the other hand, a study done in Zambia reports that insecticide resistance doesn't interrupt malaria control [68].

\section{Discussion}

This is the first paper to attempt to synthesise 42 years of data on insecticide resistance (from 1972 to 2014) in Zimbabwe. The increase in research work on the subject is evident by the higher number of papers being published on this topic; four papers in 2014 alone [5, 52, 55, 56]. A similar observation was made by Knox et al. [52], who noted an increase in the number of publications examining insecticide susceptibility and resistance in Anopheles mosquitoes in Africa. This could be due to researchers 
becoming increasingly concerned about the impact of insecticide resistance on malaria control programmes, in conjunction with their involvement in the NMCPs. Corbel and N'Guessan [21] and Ranson et al. [19] have indicated that insecticide resistance is disruptive to malaria control programmes in Africa.

The papers reviewed in this study describe fluctuations in the prevalence of resistance, with a non-uniform pattern, across Zimbabwe. In 2000, Manokore et al. [49] did not detect insecticide resistance in Gokwe. However, five and eight years later, two studies reported the presence of insecticides resistance among malarial mosquitoes in the same area [37, 54]. A nationwide survey conducted between 2011 and 2012 by Lukwa et al. [56] did not detect any insecticide resistance in malarial mosquitoes. However, Choi et al. [55] and PMI [5] reported resistance in samples collected between February and April 2014 in Honde Valley and Burma Valley, respectively, in An. funestus mosquitoes. Differences in the results of the three studies could be due to the differences in the sites sampled. Brogdon et al. [69] noted that the sites, which are only a few kilometres apart, were different not only because of the presence or absence of resistance, but also because of the varying levels of resistance and the dominant mechanisms responsible for resistance [70]. This indicates the importance of regularly sampling sentinel sites.

Despite strict rules governing insecticide use in the health and agro-industry sectors, the distribution of insecticide resistance in Zimbabwean mosquitoes seems to have been influenced by agricultural practices. The first case of insecticide resistance to BHC was reported in Chiredzi in 1972 [48]. In 2002, insecticide resistance to DDT in An. gambiae sensu lato mosquitoes was detected in Gokwe [54]. In 2008, resistance to pyrethroid (permethrin) and DDT was confirmed in Gwave, Gokwe [37]. Recently, resistance to carbamates and organochlorine was reported in An. funestus mosquitoes in Honde Valley [55] and to pyrethroids in Burma Valley [5]. Hippo Valley and the Triangle Estates are located in Chiredzi and are the sole sugar cane growers in the country. The estates have extensively used chemicals for pest control. The resistance of An. gambiae mosquitoes to DDT in Gokwe has also been attributed to the high usage of organochlorines by villagers, as well as a long history of DDT usage in this area for agricultural (especially cotton farming) and public health purposes, mainly tsetse and mosquito control [37, 54, 71]. Gipps [72] noted that Dicofol $^{\circ}$, a chlorinated hydrocarbon which is used to control spider mite in cotton, cucurbits and tomatoes, contains $20 \%$ DDT [72]. It is also believed that the water in Gokwe becomes contaminated when the pumps in the water pools are being cleaned [54]. Honde Valley and Burma Valley are also known for tea and banana farming by subsistence and commercial farmers [73].
Elsewhere in Africa, studies have attributed the high frequency of $\mathrm{kdr}$ mutations in malarial mosquitoes to extensive past use of DDT to control agricultural pests [38]. Persistent environmental contamination with organophosphate has also been a problem in Zimbabwe $[58,60,74]$. This stresses the importance of reviewing the regulations that govern the use of agricultural insecticides in Zimbabwe in order to curtail the spread of insecticide resistance.

The country's malaria control programme needs to remain vigilant. A number of studies predicted that increased temperatures in conjunction with adequate rainfall would likely cause certain mosquito-borne infections to move to higher altitudes and latitudes [75], making some areas in Zimbabwe climatologically suitable for malaria transmission [62, 64]. None of the reviewed studies attempted to sample mosquitoes in middle veld areas. Temperature can influence the development of malaria parasites in the mosquito vectors, as well as in the development of the mosquito vectors themselves [76-78]. It can also influence the survival rate of the mosquito species; their survival rate at higher latitudes and altitudes; the alteration of their vectorial susceptibility to some pathogens; the rate of the vector population growth, host contact and feeding rate; as well as the seasonality of mosquito populations [79].

Moreover, temperature can alter the genetic structure, and enzyme and protein profiles of mosquitoes and other insects $[80,81]$. For this reason, the insecticide sensitivity status of mosquitoes is inconclusive. Some studies suggest that high temperatures induce insecticide resistance in mosquitoes [43, 44]. In contrast, other studies note that high temperatures cause mosquitoes to become susceptible to insecticides [82]. In North-eastern United States, the Wyeomyia smithii mosquito species underwent genetic mutation in response to increased average land surface temperatures and spring coming earlier for two decades [83]. Although the W. smithii mosquito species is not a vector of human disease, it has similar physiological characteristics as the arbovirus species. This genetic alteration of W. smithii possibly points to similar changes occurring in malarial mosquitoes and hence underlines the need to investigate potential changes in malarial mosquitoes in Zimbabwe.

Ensuing field studies have indicated that insecticide resistance levels are dynamic and fluctuate throughout the malaria transmission season [84]. This observation may suggest that temperature might influence the development and levels of insecticide resistance, as each season has a unique average temperature.

The weakness of these studies is that they were based on different models, hypothesis and scenarios, and only a few mosquito species were investigated. Therefore, there is a need to conduct more studies in order to 
establish the effect of climate change, particularly temperature, on the development and distribution of insecticide resistance.

The current resistance situation in Zimbabwe is of public health concern as it confirms the notion that resistance in malarial mosquitoes now covers all classes of all chemicals approved for public health use [26-30]. Our review reports resistance to pyrethroids [5, 37, 55], organochlorines [54] and carbamates [55], but not organophosphates. Hence, periodic sampling of low velds and middle velds for malarial mosquitoes and testing for resistance may help in the early detection and monitoring of insecticide resistance.

Concerned with the current insecticide resistance situation, the Zimbabwe NMCP indicated, in the submission to The Global Fund's new funding model for 2015-16, that organophosphates may be used in IRS. The NMCP's plan for 2014 (October to December) was to conduct IRS using organophosphates in the areas with the highest resistance to pyrethroid. On the other hand, areas showing little or no pyrethroid resistance were to be sprayed using a mixture of pyrethroids and DDT [85]. Given that temephos (organophosphate) has already been used for larviciding in other parts of the country, it is possible that some mosquito species could now be resistant to organophosphates, the only class of insecticide in which resistance has not been reported in Zimbabwe.

The number of sites and frequency with which resistance monitoring should be conducted [86] has become a contentious issue. The number of sentinel sites that were sampled in the reviewed articles was relatively high in the 2005 survey [54] compared to the recent surveys $[5,56]$ in which there were lower, most probably due to a lack of resources. Hence, generalisation of these findings to the Zimbabwe situation needs to be done with care.

Furthermore, some studies did not sample key malaria areas. For instance, there were no sentinel sites sampled in the Kariba and Gwanda districts. In other instances, some provinces were under-represented, such as the Masvingo province in which only one rural health centre (Chilonga) was sampled, far too small to represent the entire province. The Chipinge district, which has been characterised by sporadic malaria outbreaks in previous years, was not represented in the survey [85]. This is not in line with the WHO guidelines, which state that insecticide resistance sentinel sites should be located in malaria-endemic areas with moderate to high malaria transmission rates. This means that study results not adhering to these guidelines need to be considered with caution.

It was also difficult to compare the recent countrywide survey results $[5,56]$ with the previous study done by Masendu et al. [54] due to variations in study areas (perhaps there were no sentinel sites back then). The minimum number of sampling sites should be determined considering the insecticide usage [19], location (rural and urban areas), and land use (where rice, cotton and vegetables are cultivated). It also needs to be informed by previous studies. In the recent two countrywide surveys, only one sentinel site in the urban area was sampled, yet Masendu et al. [54] observed the presence of An. arabiensis mosquitoes in the urban towns of Kwekwe, Chirundu, Kariba and Binga. Furthermore, the WHO criteria for the selection of insecticide resistance sentinel sites states that the sites should be established both in urban and rural settings [87].

Periodic seasonal sampling is recommended in order to detect seasonal resistance level variations; resistance is dynamic and wide fluctuations in resistance levels throughout the malaria transmission season have been reported [84]. This is important as resistance genes must not be allowed to build up because once they reach very high levels, strategies to restore susceptibility are unlikely to be effective [19]. Thus, regular seasonal monitoring of sentinel sites for resistance is vital in order to proactively prevent insecticides from affecting malaria control programmes.

Although the papers reviewed in this study had limitations, mainly due to a lack of resources, they do provide useful baseline information that can be used to conduct further studies on insecticide resistance, and how it might be influenced by climate change, in Zimbabwe.

\section{Conclusion}

We do not conclusively know about the distribution of resistance in mosquitoes in Zimbabwe, and therefore more work needs to be done on this topic. Available information links insecticide resistance to agricultural activities, as insecticide resistance has been observed in areas where insecticides have been extensively deployed for agricultural and public health purposes. There are no reports of insecticide resistance in middle velds, as none of the studies have made attempts to sample these areas for insecticide resistance in mosquitoes.

The Zimbabwe NMCP needs to remain vigilant. It can do this by establishing sentinel sites in the middle veld, and by conducting periodic mosquito and resistance sampling in both low and middle velds. Areas where insecticide resistance has been detected need to be identified and the type of resistance needs to be elucidated. Sentinel sites need to be encompassing land used for different purposes, such as agriculture, and include rural and urban settlements.

Given the current insecticide resistance situation in the country, with resistance to three of the four classes of the WHO-recommended IRS insecticides (with the exception of organophosphates) being reported, rotation of insecticides to organophosphates remains the only 
option to restore insecticide susceptibility. Furthermore, usage of LLINs needs to be adapted to the resistance patterns and, most importantly, the country needs to develop a national resistance management plan.

\section{Abbreviations}

BHC: Benzene hexachloride; DDT: Dichlorodiphenyltrichloroethane; GMEP: Global Malaria Eradication Programme; IRS: Insecticide residual spraying; Kdr: Knockdown resistance; LLIN: Long-lasting insecticide treated net; NMCP: National malaria control programme; PMI: President's malaria initiative; WHO: World Health Organisation.

\section{Competing interests}

This work is part of WS's PhD thesis, which seeks to assess the "Effect of temperature on insecticide resistance in laboratory-bred Anopheles gambiae mosquitoes", funded by the WHO Special Programme for Research and Training in Tropical Diseases (TDR) and the Canadian International Development Research Centre (IDRC). These institutions have no conflicting interest in the research. The authors declare that they also have no competing interests.

\section{Authors' contributions}

WS led on all aspects of the paper's development from conceptualisation to finalisation, while the other authors (MJC \& SM) were involved in the conceptualisation and reviewing of all drafts of the paper. All authors approved submission.

\section{Authors' information}

WS works for the research wing of the Zimbabwe's Ministry of Health and Child Care as a research entomologist. He is currently studying towards a $\mathrm{PhD}$ with the University of KwaZulu-Natal and focusing his research on the effect of temperature on insecticide sensitivity. MJC is the Dean of Research at the University of KwaZulu-Natal's College of Health Sciences and has supervised a number of PhD entomologists. SM is the Dean and Head of Life Sciences at the University of KwaZulu-Natal. SM has also supervised a number of $\mathrm{PhD}$ students in various fields.

\section{Acknowledgements}

This study was financially supported by the College of Health Sciences of the University of KwaZulu-Natal through PhD studentship bursary awarded to the first author. The WHO TDR and the Canadian IDRC are also thanked for their funding. Dr. Alexio Mbereko and Tawanda Manyangadze should be credited for editing this paper. This review paper was made possible by use of materials developed by other scientists. Authors of all materials used in this review paper are thus duly acknowledged.

\section{Author details}

${ }^{1}$ School of Nursing and Public Health, University of KwaZulu-Natal, Howard Campus, Durban 4001, South Africa. ${ }^{2}$ College of Health Sciences, University of KwaZulu-Natal, Durban, South Africa. ${ }^{3}$ School of Life Sciences, University of KwaZulu-Natal, KwaZulu-Natal, South Africa. ${ }^{4}$ Ministry of Health and Child Care, National Institute of Health Research, P.O. Box CY 573, Causeway, Zimbabwe.

\section{Received: 11 June 2015 Accepted: 24 September 2015} Published online: 26 October 2015

\section{References}

1. Tangpukdee N, Duangdee C, Wilairatana P, Krudsood S. Malaria diagnosis: a brief review. The Korean journal of parasitology. 2009; 47(2): 93-102.

2. WHO malaria report 2014. WHO,Geneva,2014.

3. ZNSA. Women and Men in Zimbabwe Report 2012. 2012. http://www.zimstat.co.zw/dmdocuments/Gender/Report2012.pdf. Accessed 22/07/2015.

4. Midzi S, Teveredzi V, Mudyiradima R, Chihanga S, Netsa M, Mugove A, et al. Zimbabwe Roll Back Consultative Mission (Reaping): Essential actions to support the attainment of the Abuja Targets. Harare: Roll Back Malaria; 2004.

5. PMI. |Africa IRS (AIRS). Project Indoor Residual Spraying (IRS 2) Task Order Four. In: 2013 Zimbabwe End-of-Spray Report. 2014. Bethesda, MD: PMI|Africa IRS (AIRS) Project Indoor Residual Spraying (IRS 2) Task Order Four, Abt Associates Inc; 2014.
6. Mpofu SM. Seasonal vector density and disease incidence patterns of malaria in an area of Zimbabwe. Trans R Soc Trop Med Hyg. 1985;79:169-75.

7. MoHCW. Zimbabwe National Malaria control Programme Strategy 20082013. Ministry of Health and Child Welfare Zimbabwe. 2014. http:// www.rollbackmalaria.org/files/files/countries/zimbabwe2008-2013.pdf. Accessed 7 May 2015.

8. Crees MJ. Kadoma Debrief Meeting May 1990. Blair Research Institute: Unpublished. Available at Blair Research Institute; 1990.

9. Van Lieshout M, Kovats R, Livermore M, Martens P. Climate change and malaria: analysis of the SRES climate and socio-economic scenarios. Global Environmental Change. 2004;14:87-99.

10. McMichael AJ, Woodruff RE, Hales S. Climate change and human health: present and future risks. Lancet. 2006;367:859-69.

11. Change IPOC. Climate change 2007: Impacts, adaptation and vulnerability. Suiça: Genebra; 2001.

12. Tanser FC, Sharp B, Le Sueur D. Potential effect of climate change on malaria transmission in Africa. Lancet. 2003;362:1792-8.

13. Ebi KL, Gamble JL. Summary of a workshop on the development of health models and scenarios: strategies for the future. Environ Health Perspect. 2005;113:335-8.

14. Martens W, Niessen LW, Rotmans J, Jetten TH, McMichael AJ. Potential impact of global climate change on malaria risk. Environ Health Perspect. 1995;103:458.

15. WHO. WHO Malaria Report. In: Data WLC-i-P, editor. WHO Global Malaria Programme. Geneva: WHO; 2011. p. 259.

16. WHO. Vector resistance to insecticides. 15th Report of the WHO Expert Committee on Vector Biology and Control. World Health Organization Technical Report Series. 1992;818:1-62.

17. Krostad DJ. Malaria as a reemerging disease. Epidemiol Rev. 1996;18:77-89.

18. WHO. Global Plan for Insecticide Resistance Management in Malaria Vectors (GPIRM). In: WHO/HTM/GMP/20125. Geneva, Switzerland: Organization $\mathrm{WHO} ; 2012$.

19. Ranson H, N'Guessan R, Lines J, Moiroux N, Nkuni Z, Corbel V. Pyrethroid resistance in African anopheline mosquitoes: what are the implications for malaria control? Trends Parasitol. 2011;27:91-8.

20. Hemingway J, Hawkes NJ, McCarroll L, Ranson H. The molecular basis of insecticide resistance in mosquitoes. Insect Biochem Mol Biol. 2004;34:653-65.

21. Corbel V, N'Guessan R. Distribution, Mechanisms, Impact and Management of Insecticide Resistance in Malaria Vectors: A Pragmatic Review, Anopheles mosquitoes - New insights into malaria vectors. In: Manguin S, editor. ISBN: 978-953-51-1188-7, InTech, doi:10.5772/56117; 2013. Available from: http:// www.intechopen.com/books/anopheles-mosquitoes-new-insights-intomalaria-vectors/distribution-mechanisms-impact-and-management-ofinsecticide-resistance-in-malaria-vectors-a-pragmat.

22. Wood R, Pasteur N, Sinegre G. Carbamate and organophosphate resistance in Culex pipiens L. (Diptera: Culicidae) in southern France and the significance of Est-3A. Bull Entomol Res. 1984;74:677-87.

23. Livadas GA, Georgopoulos G. Development of resistance to DDT by Anopheles sacharovi in Greece. Bull World Health Organ. 1953;8(4):497-511.

24. Brown AWA. Insecticide Resistance in Arthropods World Health Organization, Geneva. 1958.

25. Georghiou G, Ariaratnam V, Pasternak M, Lin CS. Organophosphorus multiresistance in Culex pipiens quinquefasciatus in California. J Econ Entomol. 1975;68:461-7.

26. Hemingway J, Ranson $\mathrm{H}$. Insecticide resistance in insect vectors of human disease. Annu Rev Entomol. 2000;45:371-91.

27. Coetzee M, Horne D, Brooke B, Hunt R. Ddt, Dieldrin And Pyrethroid Insecticide Resistance In African Malaria Vector Mosquitoes: An Historical Review And Implications For Future Malaria Co Ntrol In Southern Africa. S Afr J Sci. 1999:95:215-8.

28. Etang J, Manga L, Chandre F, Guillet P, Fondjo E, et al. Insecticide susceptibility status of Anopheles gambiae sl (Diptera: Culicidae) in the Republic of Cameroon. J Med Entomol. 2003;40:491-7.

29. Coetzee M, Van Wyk P, Booman M, Koekemoer L, Hunt R. Entomologie MÉDICALE. Bull Soc Pathol Exot. 2006:99:400-3.

30. Abdalla H, Matambo T, Koekemoer L, Mnzava A, Hunt R, Coetzee M. Insecticide susceptibility and vector status of natural populations of Anopheles arabiensis from Sudan. Trans R Soc Trop Med Hyg. 2008;102:263-71.

31. Elissa N, Mouchet J, Rivière F, Meunier J-Y, Yao K. Resistance of Anopheles gambiae ss to pyrethroids in Côte d'Ivoire: Ann Soc Bel Med Trop. 1993;73(4):291-294 
32. Enayati $\mathrm{A}$, Vatandoost $\mathrm{H}$, Ladonni $\mathrm{H}$, Townson $\mathrm{H}$, Hemingway J. Molecular evidence for a kdr-like pyrethroid resistance mechanism in the malaria vector mosquito Anopheles stephensi. Med Vet Entomol. 2003;17:138-44.

33. Singh OP, Bali P, Hemingway J, Subbarao SK, Dash AP, Adak T. PCR-based methods for the detection of L1014 kdr mutation in Anopheles culicifacies sensu lato. Malar J. 2009:8:154.

34. Diabate A, Baldet T, Chandre F, Akoobeto M, Guiguemde TR, Darriet F, et al. The role of agricultural use of insecticides in resistance to pyrethroids in Anopheles gambiae sl in Burkina Faso. Am J Trop Med Hyg. 2002;67:617-22.

35. Vulule J, Beach R, Atieli F, Roberts J, Mount D, Mwangi R, et al. Reduced susceptibility of Anopheles gambiae to permethrin associated with the use of permethrin-impregnated bednets and curtains in Kenya. Med Vet Entomol. 1994:8:71-5.

36. Hargreaves K, Koekemoer L, Brooke B, Hunt R, Mthembu J, Coetzee M, et al. Anopheles funestus resistant to pyrethroid insecticides in South Africa. Med Vet Entomol. 2000;14:181-9.

37. Munhenga G, Masendu HT, Brooke BD, Hunt RH, Koekemoer LK. Pyrethroid resistance in the major malaria vector Anopheles arabiensis from Gwave, a malaria-endemic area in Zimbabwe. Malar J. 2008;7:247.

38. Akogbeto M, Djouaka R, Noukpo H. Use of agricultural insecticides in Benin. Bulletin de la Societe de pathologie exotique (1990). 2005:98:400-5.

39. Hougard J-M, Duchon S, Zaim M, Guillet P. Bifenthrin: a useful pyrethroid insecticide for treatment of mosquito nets. J Med Entomol. 2002;39:526-33.

40. Brogdon WG, McAllister JC. Insecticide resistance and vector control. Emerg Infect Dis. 1998;4:605.

41. Lines J. Do agricultural insecticides select for insecticide resistance in mosquitoes? A look at the evidence. Parasitol Today. 1988;4:S17-20.

42. Hamdan H, Sofian-Azirun M, Nazni W, Lee H. Insecticide resistance development in Culex quinquefasciatus (Say), Aedes aegypti (L.) and Aedes albopictus (Skuse) larvae against malathion, permethrin and temephos. Trop Biomed. 2005;22:45-52.

43. Raghavendra K, Barik TK, Adak T. Development of larval thermotolerance and its impact on adult susceptibility to malathion insecticide and Plasmodium vivax infection in Anopheles stephensi. Parasitol Res. 2010;107:1291-7.

44. Patil NS, Lole KS, Deobagkar DN. Adaptive larval thermotolerance and induced cross-tolerance to propoxur insecticide in mosquitoes Anopheles stephensi and Aedes aegypti. Med Vet Entomol. 1996;10:277-82.

45. Brogdon WG, Fiore A, Kachur SP, Slutsker L, Wirtz RA. Insecticide Resistance and Malaria. In: A Threat Decades in the Making. Washington, DC 20036: Centre for Strategic \& International Studies; 2014. p. 1-6.

46. Zahar AR. The vector bionomics in the epidemiology and control of malaria Part 1. In The WHO African Region and the Southern WHO Eastern Mediterranean Region World Health Organisation Geneva; 1985.

47. Mabaso ML, Sharp B, Lengeler C. Historical review of malarial control in southern African with emphasis on the use of indoor residual housespraying. Trop Med Int Health. 2004;9:846-56.

48. Green CA. Malaria epidemiology and anopheline cytogenetics. In: Pal R, Kitzmiller JB, Kanda T, Pal R, Kitzmiller JB, Kanda T, editors. Cytogenetics and Genetics of Vectors. Amsterdam; OpenURL 21-29: Elsevier Biomedical; 1982.

49. Manokore V, Murahwa F, Chirebvu E. Absence of insecticide resistance in Anopheles gambiae sl (Diptera: Culicidae) after four decades of residual house spraying in Gokwe District, Zimbabwe. J Med Entomol. 2000;37:286-8.

50. Stockholm Convention. Report of stakeholders' Meeting to Review the Interim report to Establish a Global Partnership to Develop Alternatives to DDT, Geneva, 3-5 November 2008. Report No.UNEP/POPS/DDT-BP.1/12, Stockholm Convention on Persistent Organic Pollutants, Geneva. 2008.

51. Phelps R, Focardi S, Fossi C, Leonzio C, Renzoni A. Chlorinated hydrocarbons and heavy metal in crocodile eggs from Zimbabwe. Transactions of the Zimbabwe Scientific Association. 1986;63:8-15.

52. Knox TB, Juma EO, Ochomo EO, Pates Jamet $H$, Ndungo $L$, Chege $P$, et al. An online tool for mapping insecticide resistance in major Anopheles vectors of human malaria parasites and review of resistance status for the Afrotropical region. Parasit Vectors. 2014;7:76.

53. Sinka ME, Bangs MJ, Manguin S, Rubio-Palis Y, Chareonviriyaphap T, Coetzee $\mathrm{M}$, et al. A global map of dominant malaria vectors. Parasit Vectors. 2012;5:69.

54. Masendu H, Hunt R, Koekemoer L, Brooke B, Govere J, Coetzee M, et al. Spatial and temporal distributions and insecticide susceptibility of malaria vectors in Zimbabwe. African entomology. 2005;13:25-34.

55. Choi KS, Christian R, Nardini L, Wood OR, Agubuzo E, Muleba M, et al. Insecticide resistance and role in malaria transmission of Anopheles funestus populations from Zambia and Zimbabwe. Parasites \& vectors. 2014;7:464.

56. Lukwa N, Sande S, Makuwaza A, Chiwade T, Netsa M, Asamoa K, et al. Nationwide assessment of insecticide susceptibility in Anopheles gambiae populations from Zimbabwe. Malar J. 2014;13:408.

57. Coetzee M. Distribution of the African malaria vectors of the Anopheles gambiae complex. Am J Trop Med Hyg. 2004;70:103-4.

58. Mpofu SM. DDT and its use in Zimbabwe. Zim. Sci.News. 1987,21:31-36.

59. Zaranyika MF, Makhubalo JM. Organochlorine pesticide residues in inland waters in Zimbabwe. Pesticides in Zimbabwe: Toxicity and Health Implications The University of Zimbabwe Publications, Harare; 1996. p. 89-106.

60. Chikuni O, Nhachi C, Nyazema N, Polder A, Nafstad I, Skaare J, et al. Assessment of environmental pollution by PCBs, DDT and its metabolites using human milk of mothers in Zimbabwe. Sci Total Environ. 1997;199:183-90.

61. Leeson H. Anopheline Mosquitos in Southern Rhodesia 1926-1928. Mem Lond Sch: Hyg trop Med; 1931.

62. Ebi KL, Hartman J, Chan N, Mcconnell J, Schlesinger M, Weyant J, et al. Climate suitability for stable malaria transmission in Zimbabwe under different climate change scenarios. Climatic Change. 2005;73:375-93.

63. Komen $\mathrm{KO}$, J Rautenbach, H Botai, J Adebayo. A Long-Run Relative Importance of Temperature as the Main Driver to Malaria Transmission in Limpopo Province, South Africa: A Simple Econometric Approach. EcoHealth; 2015;12:131-143. doi:10.1007/s10393-014-0992-1.

64. Mabaso ML, Vounatsou P, Midzi S, Da Silva J, Smith T. Spatio-temporal analysis of the role of climate in inter-annual variation of malaria incidence in Zimbabwe. Int J Health Geogr. 2006;5:20.

65. Wondji CS, Coleman M, Kleinschmidt I, Mzilahowa T, Irving H, Ndula M, et al Impact of pyrethroid resistance on operational malaria control in Malawi. Proc Natl Acad Sci. 2012;109:19063-70.

66. Trape J-F, Tall A, Diagne N, Ndiath O, Ly AB, Faye J, et al. Malaria morbidity and pyrethroid resistance after the introduction of insecticide-treated bednets and artemisinin-based combination therapies: a longitudinal study. Lancet Infect Dis. 2011;11:925-32.

67. Sharp BL, Ridl FC, Govender D, Kuklinski J, Kleinschmidt I. Malaria vector control by indoor residual insecticide spraying on the tropical island of Bioko, Equatorial Guinea. Malar J. 2007;6:52.

68. Chanda E, Hemingway J, Kleinschmidt I, Rehman AM, Ramdeen V, Phiri FN, et al. Insecticide resistance and the future of malaria control in Zambia. PLoS One. 2011;6:e24336.

69. Brogdon WG, Beach RF, Stewart JM, Castanaza L. Microplate assay analysis of the distribution of organophosphate and carbamate resistance in Guatemalan Anopheles albimanus. Bull World Health Org. 1988:66:339.

70. Brogdon WG, MCAllister JC. Simplification of adult mosquito bioassays through use of time-mortality determinations in glass bottles. J Am Mosq Control Assoc. 1998;14:159-64.

71. Matthiesen P. DDT insecticide residues in Zimbabwean wildlife and their potential environmental impact. Zimbabwe: Zimbabwe Science News; 1985.

72. Gipps T. Breaking the Pesticide Habit: Alternatives to 12 Hazardous Pesticides. International Alliance for Sustainable Agriculture. Malaysia: Penang: International Organization of Consumers Unions; 1987.

73. Boonstoppel E, Mudyazvivi E. The case of making teaching and learning materials practical and locally relevant in Zimbabwe. SNV Netherlands Development Organisation Case Studies. 2010;1-4.

74. Zaranyika M, Mambo E, Makhubalo J. Organochlorine pesticide residues in the sediments of selected river bays in Lake Kariba, Zimbabwe. Sci Total Environ. 1994;142:221-6.

75. IPCC (2007) Contribution of Working Group II to the Fourth Assessment Report of the Intergovernmental Panel on Climate Change. In: Parry M.L. Canziani O.F., Palutikof J.P., van der Linden P.J., Hansoni C.E., editors. Cambridge:Cambridge University Press.

76. Githeko AK, Lindsay SW, Confalonieri UE, Patz JA. Climate change and vector-borne diseases: a regional analysis. Bull World Health Org. 2000;78:1136-47

77. Hales S, De Wet N, Maindonald J, Woodward A. Potential effect of population and climate changes on global distribution of dengue fever: an empirical model. Lancet. 2002;360:830-4.

78. Patz JA, Martens W, Focks DA, Jetten TH. Dengue fever epidemic potential as projected by general circulation models of global climate change. Environ Health Perspect. 1998;106:147. 
79. Patz JA, Githeko AK, McCarty JP, McCarty P, Hussein S, Confaloniera U, et al. Climate change and infectious diseases. Climate Change and Human Health: Risks and Responses. Geneva, Switz: World Health Organization; 2003. p.103-32.

80. Yan G, Chadee DD, Severson DW. Evidence for genetic hitchhiking effect associated with insecticide resistance in Aedes aegypti. Genetics. 1998;148:793-800.

81. Imasheva AG, Loeschcke V, Zhivotovsky LA, Lazebny OE. Effects of extreme temperatures on phenotypic variation and developmental stability in Drosophila melanogaster and Drosophila buzzatii. Biological Journal of the Linnean Society. 1997;61:117-26.

82. Polson KA, Brogdon WG, Rawlins SC, Chadee DD. Impact of environmental temperatures on resistance to organophosphate insecticides in Aedes aegypti from Trinidad. Revista Panamericana de Salud Pública. 2012;32:1-8.

83. Bradshaw WE, Holzapfel CM. Genetic shift in photoperiodic response correlated with global warming. Proc Natl Acad Sci. 2001;98:14509-11.

84. Ranson H, Abdallah H, Badolo A, Guelbeogo WM, Kerah-Hinzoumbé C, et al. Insecticide resistance in Anopheles gambiae: data from the first year of a multi-country study highlight the extent of the problem. Malar J. 2009:8:299.

85. USAID C. PRESIDENT'S MALARIA INITIATIVE Zimbabwe Malaria Operational Plan FY (2015) http://www.pmi.gov/docs/default-source/default-documentlibrary/malaria-operational-plans/fy-15/fy-2015-zimbabwe-malariaoperational-plan.pdf?sfvrsn=3. Accessed 5 June 2015.

86. Kelly-Hope L, Ranson H, Hemingway J. Lessons from the past: managing insecticide resistance in malaria control and eradication programmes. Lancet Infect Dis. 2008:8:387-9.

87. Kabula B, Tungu P, Matowo J, Kitau J, Mweya C, Emidi B, et al. Susceptibility status of malaria vectors to insecticides commonly used for malaria control in Tanzania. Tropical Medicine \& International Health. 2012;17:742-50.

\section{Submit your next manuscript to BioMed Central and take full advantage of:}

- Convenient online submission

- Thorough peer review

- No space constraints or color figure charges

- Immediate publication on acceptance

- Inclusion in PubMed, CAS, Scopus and Google Scholar

- Research which is freely available for redistribution 